\title{
Measuring Behavioural Intention through the Use of Greenwashing: A Study of the Mediating Effects and Variables Involved
}

\author{
Eloy Gil-Cordero * ${ }^{\mathbb{D}}$, Juan Pedro Cabrera-Sánchez $\mathbb{C}^{\mathbb{D}}$, Ignacio Cepeda-Carrión and Jaime Ortega-Gutierrez
}

\section{check for}

updates

Citation: Gil-Cordero, E.;

Cabrera-Sánchez, J.P.;

Cepeda-Carrión, I.; Ortega-Gutierrez,

J. Measuring Behavioural Intention

through the Use of Greenwashing: A

Study of the Mediating Effects and

Variables Involved. Sustainability

2021, 13, 6720. https://doi.org/

$10.3390 /$ su13126720

Academic Editors: Gianluigi Guido, Cristian Rizzo and Luigi Piper

Received: 30 April 2021

Accepted: 10 June 2021

Published: 14 June 2021

Publisher's Note: MDPI stays neutral with regard to jurisdictional claims in published maps and institutional affiliations.

Copyright: (c) 2021 by the authors. Licensee MDPI, Basel, Switzerland. This article is an open access article distributed under the terms and conditions of the Creative Commons Attribution (CC BY) license (https:/ / creativecommons.org/licenses/by/ $4.0 /)$.
Department of Business Administration and Marketing, University of Seville, 41018 Seville, Spain; jcabrera10@us.es (J.P.C.-S.); icepeda@us.es (I.C.-C.); joguti@us.es (J.O.-G.)

* Correspondence: egcordero@us.es

Abstract: The work aims to achieve a better understanding of firms' green strategy, and specifically, in the false green strategy called greenwashing, and the relationships between greenwashing (GW) and behaviour intention (BI), and how this relationship is affected by word of mouth (WOM) and corporative social responsability (CRS). A survey was conducted and 198 valid and complete online questionnaires were collected from users of urban mobility apps (Blablacar and Amovens) in Spain. The structural equation modeling technique partial least squares (PLS-SEM) was used to test the proposed research model and hypothesized relationships. The results of our study indicate that the direct relationship between GW and BI is not supported, although the indirect relationship through WOM and CRS is significant, so that both become mediating variables of the GW and BI relationship. The paper also analyzes the direct relationships between GW, CRS, WOM and BI, so that the direct effects GW and CRS; CRS and WOM; and WOM and BI are significant. This empirical study analyzes the effect of GW, which has not been studied much, especially in empirical research. The study analyzes several variable consequences of GW and analyzes mediating effects of CRS and WOM on the GW and BI relationship. The study also includes two behavioral indicators, WOM and BI, in a research model, and, additionally, the study demonstrates the relationship between GW and perceived CRS.

Keywords: greenwashing; word of mouth; corporative social responsibility; behaviour intention; partial least square

\section{Introduction}

In a review of the literature since the 1990s, we found the many businesses [1-12] and researchers that benefited from green marketing continue to rely on these benefits nearly 30 years later [13-16]. We define green marketing as the set of activities designed to generate and facilitate any exchange aimed at satisfying human needs or desires, in such a way that these needs and desires are met, with a minimum harmful impact on the natural environment. As Marikyan et al. (2019) [17] tell us, the economic profitability of smart homes is often coupled with environmental gains.

However, there is a trend in the literature on the opposite side of green marketing since, as a consequence of the concept, consumers are discovering the opportunistic advantages that companies have towards these environmental advantages [18]. In this sense, companies that promote their products using the support of the environment have apparently become "greener" in recent years [19]. As a result of all of the above, the concept of "greenwashing" appears, which was first used by Jay Westerveld in the 1980s, with most researchers in the field agreeing with what was said earlier, that companies are becoming "greener" [20-24]. One of the concepts about greenwashing (GW) most accepted by the research community was taken up by researchers Parguel et al. [25], defining it as "the practices carried out by companies to appeal the excessive functionality of their product on 
the environment and which cannot be sustained". Another of the most widely accepted concepts about greenwashing is the one provided by the authors Delmas and Burbano [26], stating that greenwashing is an intersection of two firm behaviors: Poor environmental performance and positive communication about environmental performance.

With the rise of the concept and its implication in society, numerous investigations have emerged on the accumulated inconveniences of the use of greenwashing, some of them referring to the negative implication that affects behaviour intention [27] and corporate social responsibility [28].

The main objective of this research is to develop a model to measure the impact of greenwashing on CSR and WOM and these in turn on behaviour intention. It is also our aim to bring to the scientific community the opportunistic aspect that many companies have adopted concerning the use of a non-real green strategy, in order to benefit themselves and impact their bottom line. Specifically, we want to highlight those companies that use "green" as a business strategy, rather than as a company philosophy, which is really what the market demands.

The structure of this article begins first with an introduction to the topic of green marketing and greenwashing, defining both concepts and outlining when they first appeared in the literature. In the second part, we develop the theoretical part focusing on the different variables that we include in the model, as well as the development and approach of the set of hypotheses. Finally, we present the resulting model of our research graphically, the results and the conclusions.

\section{Theoretical Framework}

\subsection{Perceived CSR}

Corporate Social Responsibility (CSR) is a set of voluntary actions that benefit the company and society as a whole [29]. Increased corporate social responsibility is based on a concern with responding appropriately to society, that being part of the criteria that stakeholders have to judge business behavior.

According to Kraus et al. [30] the aspect of social and environmental sustainability is a potential source of ideas to improve the environment. Moreover, the lack of compliance with CSR can become a threat to the reputation and prosperity of companies [31].

Consequently, the theories that support perceived CSR in the literature recognize that companies must take into account the interests of different stakeholders, including customers, partners, suppliers, employees and communities, in business decisionmaking [32,33]. In this sense, there is a great fear among directors that they will be accused of greenwashing [34] and that, therefore, the company's perceived CSR may be understood as such [28]. This is determined when people perceive that a company that is proud of its social work can hide an opportunistic intention [35]. Therefore, it is necessary to know what influence greenwashing can have on corporate social responsibility.

In addition to the above, and once the relationship between greenwashing and perceived corporate social responsibility is known, it is necessary to take into account that perceived CSR is a determining value within the company that in turn not only motivates current customers to adopt a favorable attitude, but also potential customers. Potential customers learn of corporations from their advertisements and other sources, for example, word of mouth from existing customers [36]. Other authors such as Chomvilailuk and Butcher establish that perceived CSR is an influential factor in the word of mouth of customers [37], but it is necessary to know whether the sample of this last study is corroborated in other countries; therefore, and in addition to knowing the relationship between greenwashing and perceived CSR, it is also necessary to know the influence of the latter on WOM. Perri et al. (2020) [38] show in their results that remedies aimed at increasing the awareness of purchasing level staff can be beneficial, while initiatives that involve experts in the field may be significantly less useful.

Finally, in the literature we find that researchers such as Bigne-Alcañiz and CurrásPérez in 2008 suggest that perceived CSR is an influential factor in behaviour intention 
(BI) [39], but given that perceived CSR is a construct that is constantly evolving and depends on the current situation of the business ecosystem [40] it is necessary to verify whether this relationship is currently confirmed.

For all the above reasons, we propose the following hypotheses:

Hypothesis 1. Greenwashing has a negative influence on perceived CSR.

Hypothesis 2. Perceived CSR has a positive influence on BI.

Hypothesis 3. Perceived CSR has a positive influence on WOM.

\subsection{WOM}

WOM has traditionally been conceptualized as the exchange of interpersonal information between individuals who know each other [41]. In this regard, it has been established from the outset as the exchange of marketing information between consumers in such a way that it plays a fundamental role in shaping their behavior and changing their attitudes towards products and services [42].

This concept has evolved along with the growing concern about global warming, so consumers are more aware of environmental considerations [43]. Some companies are using this scenario to selectively reveal positive information about the environmental characteristics of their products without revealing negative information in order to generate a green image [44], thereby generating negative communications from consumers resulting in what is considered "green wom", defined by Chen et al. as the extent to which a customer would influence friends, relatives and colleagues on the positive or negative environmental messages of a product or brand [45]. Thus, it should be noted that researchers claim that consumer-to-consumer communication, such as word of mouth, triggers a strong and credible influence on consumer behavior [46,47], and that if we use environmental benefits in a negative way, we may incur what is known as greenwashing. Therefore, they can cause damage to the perceived quality of a brand. This statement has been verified by Chen, exposing the negative relationship between greenwashing and WOM [45], but has not considered whether this pattern is verified with BI. On the other hand, other recent studies such as that of Zhang et al. have verified whether consumer perceptions of greenwashing have a negative effect on BI for green products in addition to studying in the same research the negative indirect effects through WOM [48]. However, this last study is based on a sample located in China, so it is necessary to know if these results are fulfilled in other countries.

For all the above reasons, we propose the following hypotheses:

Hypothesis 4. Greenwashing has a negative influence on WOM.

Hypothesis 5. WOM has a positive influence on the BI.

\subsection{Behaviour Intention}

Behaviour intention (BI) is defined in the literature as those signals that show whether a customer continues to use a company's service or changes its supplier [49]. This concept has been widely studied by several authors to determine the background affecting consumers when choosing a product or service [50-52].

It is now widely accepted that consumers' behaviour intention is influenced by emotions during the stages before, during and after consumption of the product or service $[53,54]$, which, together with the information the consumer has about the company's environmentally sustainable behavior, determine an important role in the future BI [55]. Balta-Ozkan et al. (2014) [56] take this work as an example in a paper where they compared rural and urban areas in several countries where citizens show different attitudes towards environmental benefit. The research showed that environmental sustainability has become a more significant element for urban dwellers. This is explained by the greater role of 
economic benefit for urban dwellers, which far outweighs environmental concerns. In this line, previous studies have shown the positive influence that the BI has with respect to products that are responsible with the environment [57] and, at the same time, they warn that not all companies make good use of this information, leading to greenwashing [26]. In this sense, some previous studies establish that the relationship between greenwashing and BI is mediated by trust and WOM [58], but they do not incorporate in this mediation the perceived CSR despite the fact that some researchers suggest that the perceived CSR is an influential factor in the BI [39]. In the prior literature, it has been investigated which are possible antecedents of behavioral intention, and, specifically, the studies of Song et al. (2008) [59] show how communication between consumers (WOM) positively impacts on behavioral intention, and on the other hand whether, if customers have a positive perception of the company as socially responsible, they tend to adopt favorable behavior towards that organization [60]. In addition, it would be important to extend the sample of this research to check if it is verified in other countries.

For all the above reasons, we propose the following hypotheses:

Hypothesis 6. Greenwashing has a negative influence on BI.

These 6 hypotheses are direct hypotheses and because of that are drawn in continuous lines in the proposed model shown in Figure 1.

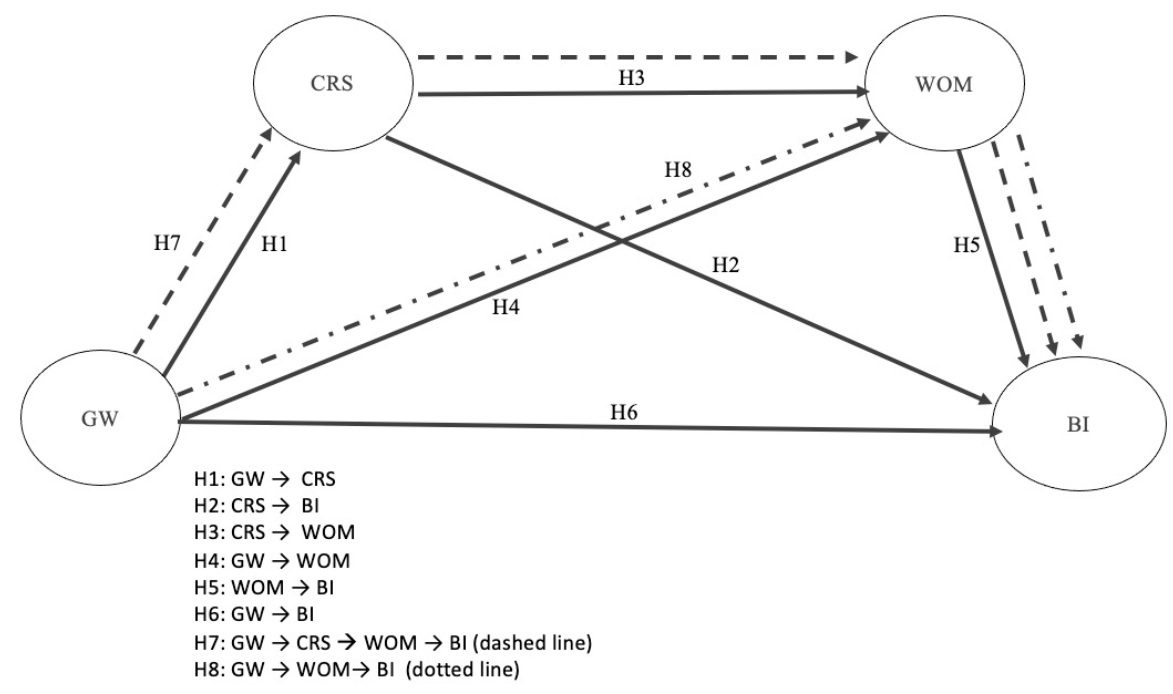

Figure 1. Research proposed model.

Additionally we propose two more hypotheses but in this case; they are indirect effects. That is why they are drawn in dotted and dashed lines. These hypotheses are:

Hypothesis 7. The path from Greenwashing to BI is mediated by the next sequence of mediators: CRS and WOM.

Hypothesis 8. The path from Greenwashing to BI is mediated by WOM.

\section{Methodology}

\subsection{Data Collection and Sampling}

The population of this study was the customers or users of the Blablacar and Amovens urban mobility mobile apps. They are all 18 years old or older customers. The questionnaires were sent by email with a link to access the questions. Questionnaires were sent to 345 users of these apps, and a total of 198 valid questionnaires were collected between February and March 2020. 
Responses from a total of 105 women (53\%) and 93 men (47\%) were collected. For each item, participants indicated how they agreed or disagreed, and all items were rated on a seven-point Likert scale ranging from 1 (strongly disagree) to 7 (strongly agree).

\subsection{Measure}

In this study we used existing scales taken from previous literature studies. The questionnaire includes:

(a) Green Washing (GW). The elements were measured using a seven-point Likert scale from the study of Laufer [61]. This scale is a one-dimensional scale with five items.

(b) Perceived Corporate Social Responsibility (CSR). This construct used the one-dimensional scale of five items from the study by Ramasamy et al. [33].

(c) Word of mouth (WOM). This study used the one-dimensional adapted scale of six items of the study of Goyette et al. [62].

(d) Behavioral intention (BI). This study used the one-dimensional scale of three items from the study by $\mathrm{Xu}$ et al. [63].

\subsection{Data Analysis}

For the data analysis, this study used the technique of structural equation modelling (SEM) based on variance, Partial Least Square (PLS-SEM).

In recent times, SEM techniques have been growing and evolving with technological development. The SEM technique belongs to the family of multivariate analysis, where multiple variables are analyzed that in our research field are related to companies, managers, clients, etc. This SEM technique is also considered a second generation of data analysis techniques and has been used by social researchers for the last 30 years. There are two typologies of SEM techniques, those based on covariance (CB-SEM) and those based on variance (partial least square-PLS-SEM). The first uses common factor models to represent latent variables, and the second uses compound factor models [64].

In this regard, Rigdon (2016) identifies several reasons that should not be used as a pretext for using PLS-SEM: The small sample size; an unusual data distribution; the existence of formative indicators; and the statement of exploratory research.

More recently, Ali et al. [65], Rigdon [64], and Rigdon et al. [66] emphasized that researchers should use that technique to analyze the data that is consistent with the type of model they want to try to estimate, and therefore they want to say that it is very important that researchers indicate the type of model to estimate, and thus determine the type of technique to treat the data most appropriately.

More generally, the PLS-SEM researchers agree that in those models that only use common factors, techniques based on covariance (CB-SEM) would be mainly used. While those researchers using composites would use methods based on PLS-SEM type composites [67], and in the case of mixed models, where both types are used, the option would be to use the consistent PLS version (PLSc) [68]. Based on these considerations, it is reasonable to assume that the first reason for using PLS-SEM is according to the type of latent variable in the model that the researchers are trying to estimate.

In this study, all measurements were operationalized as composites [66,69], therefore, we chose to use a structural equation modeling technique, partial least squares (PLS-SEM), to test the model proposed by the research and the hypothesized relationships. Two reasons support this technique: First, following Hair et al. [70] and Rigdon et al. [66], we used Mode A composites; second, according to Henseler [71], we chose an explanatory approach. From here, we developed a two-step process with PLS for the evaluation of the proposed model. First, the measurement model is analyzed, and second, the structural model will be analyzed [72].

In order to find the importance of the indices, we carried out a bootstrapping process [73].

For the analysis of the data we used the software SmartPLS 3.2.6 according to Ringle et al. (2015) and for the analysis of the mediating effects we followed the process developed by Cepeda-Carrion et al. [74]. 
According to Henseler et al. [75], the most suitable measures for internal reliability would be $\rho$ A, Jöreskog's rho and Cronbach's alpha. Values above 0.7 indicate an adequate level of reliability [76]. Through the AVE (mean variance extracted) we analyzed the unidimensionality according to Fornell-Larcker [77]. Finally, following Hair et al. [78], to evaluate discriminant validity, we followed the HTMT criterion (heterotrait-monotrait ratio).

\section{Results}

From the indicated PLS-SEM technique, the following results were obtained by analyzing on one hand the measurement model and on the other hand the structural model.

\subsection{Measurement Model}

As for the measurement model, it should be noted that all items meet the prerequisite of reliability since all loads are greater than 0.7 (Table 1) and consistent measurements are greater than 0.8 [79].

Table 1. Indicator correlation weights.

\begin{tabular}{ccccc}
\hline & GW & BI & CSR & WOM \\
\hline GW1 & 0.867 & & & \\
GW2 & 0.914 & & & \\
GW3 & 0.834 & & & \\
GW4 & 0.866 & & & \\
GW5 & 0.802 & 0.846 & & \\
BI1 & & 0.904 & 0.789 & \\
BI2 & 0.865 & 0.848 & \\
BI3 & & 0.795 & \\
CSR1 & & 0.903 & 0.896 \\
CSR2 & & & 0.901 \\
CSR3 & & & 0.844 \\
CSR4 & & & 0.871 \\
CSR5 & & & 0.727 \\
WOM1 & & & 0.911 \\
WOM2 & & & \\
WOM3 & & & \\
WOM4 & & & & \\
WOM5 & & & \\
WOM6 & & & & \\
\hline
\end{tabular}

Notes: GW: Greenwashing; BI: Behaviour intention; CSR: Corporate social responsibility; WOM: Word of mouth.

The reliability of the scales was evaluated according to the results obtained (this is reflected in Table 2) by checking if the Cronbach's Alpha of each scale is higher than the threshold of 0.70 [80]. Composite reliability (CR) [81] is considered a better measure of reliability since it does not assume the equalization of the items, and the value of the average variance (AVE) is greater than 0.5 in all cases [72].

Table 2. Construct reliability and convergent validity coefficients.

\begin{tabular}{ccccc}
\hline & CA & rho_A & CR & AVE \\
\hline GW & 0.912 & 0.946 & 0.933 & 0.735 \\
BI & 0.842 & 0.846 & 0.905 & 0.760 \\
CSR & 0.870 & 0.879 & 0.907 & 0.661 \\
WOM & 0.929 & 0.935 & 0.945 & 0.741 \\
\hline
\end{tabular}

Notes: $\mathrm{CA}=$ Cronbach's alpha; $\mathrm{CR}=$ composite reliability; AVE = average variance extracted.

In Table 3, we can see that all variables present discriminant validity based on heterotrait-monotrait ratio (HTMT) criteria. 
Table 3. Discriminant validity. Heterotrait-monotrait ratio (HTMT).

\begin{tabular}{ccccc}
\hline & GW & BI & CSR & WOM \\
\hline GW & & & & \\
BI & 0.202 & & & \\
CSR & 0.246 & 0.198 & 0.312 & \\
WOM & 0.169 & 0.763 & & \\
\hline
\end{tabular}

Notes: GW: Greenwashing; BI: Behaviour intention; CSR: Corporate social responsibility; WOM: Word of mouth.

\subsection{Structural Model}

The validation of the structural model will be done according to the significance of the model's coefficients, using the bootstrap method, with 5000 samples with replacement of the same size as the original sample (198 observations) [82].

Data from the analysis of the structural model are indicated in Table 4 and in the Figure 2.

Table 4. Construct effects on endogenous variables (including lower and upper limits of 95\% confidence interval).

\begin{tabular}{|c|c|c|c|c|c|}
\hline \multirow{2}{*}{$\begin{array}{c}\text { Effects on Endogenous } \\
\text { Variables }\end{array}$} & \multirow{2}{*}{ Path Coeff. } & \multicolumn{2}{|c|}{ Confidence Intervals (95\%) } & \multirow{2}{*}{$\begin{array}{l}\text { Significance of Effect } \\
(p \text {-Value })\end{array}$} & \multirow{2}{*}{$\begin{array}{l}\text { R [2] Dependent } \\
\text { Constructs }\end{array}$} \\
\hline & & $5 \%$ CIlo & 95\%CIhi & & \\
\hline $\mathrm{GW} \rightarrow \mathrm{CSR}(\mathrm{H} 1)$ & -0.216 & -0.369 & -0.041 & Yes (0.009) & 0.046 \\
\hline $\mathrm{CSR} \rightarrow \mathrm{BI}(\mathrm{H} 2)$ & -0.039 & -0.138 & 0.063 & No $(0.447)$ & 0.450 \\
\hline $\mathrm{CSR} \rightarrow \mathrm{WOM}(\mathrm{H} 3)$ & 0.263 & 0.109 & 0.415 & Yes $(0.001)$ & 0.105 \\
\hline $\mathrm{GW} \rightarrow \mathrm{WOM}(\mathrm{H} 4)$ & -0.115 & -0.281 & 0.064 & No $(0.186)$ & 0.150 \\
\hline $\mathrm{WOM} \rightarrow \mathrm{BI}(\mathrm{H} 5)$ & 0.673 & 0.573 & 0.756 & Yes $(0.000)$ & 0.450 \\
\hline $\mathrm{GW} \rightarrow \mathrm{BI}(\mathrm{H} 6)$ & -0.086 & -0.196 & 0.022 & No $(0.125)$ & 0.450 \\
\hline $\mathrm{GW} \rightarrow \mathrm{CSR} \rightarrow \mathrm{WOM} \rightarrow \mathrm{BI}(\mathrm{H} 7)$ & -0.038 & -0.027 & -0.075 & Full Mediation & 0.450 \\
\hline $\mathrm{GW} \rightarrow \mathrm{WOM} \rightarrow \mathrm{BI}(\mathrm{H} 8)$ & -0.077 & -0.224 & 0.010 & No (0.185) & 0.450 \\
\hline
\end{tabular}

Notes: GW: Greenwashing; BI: Behaviour intention; CSR: Corporate social responsibility; WOM: Word of mouth.

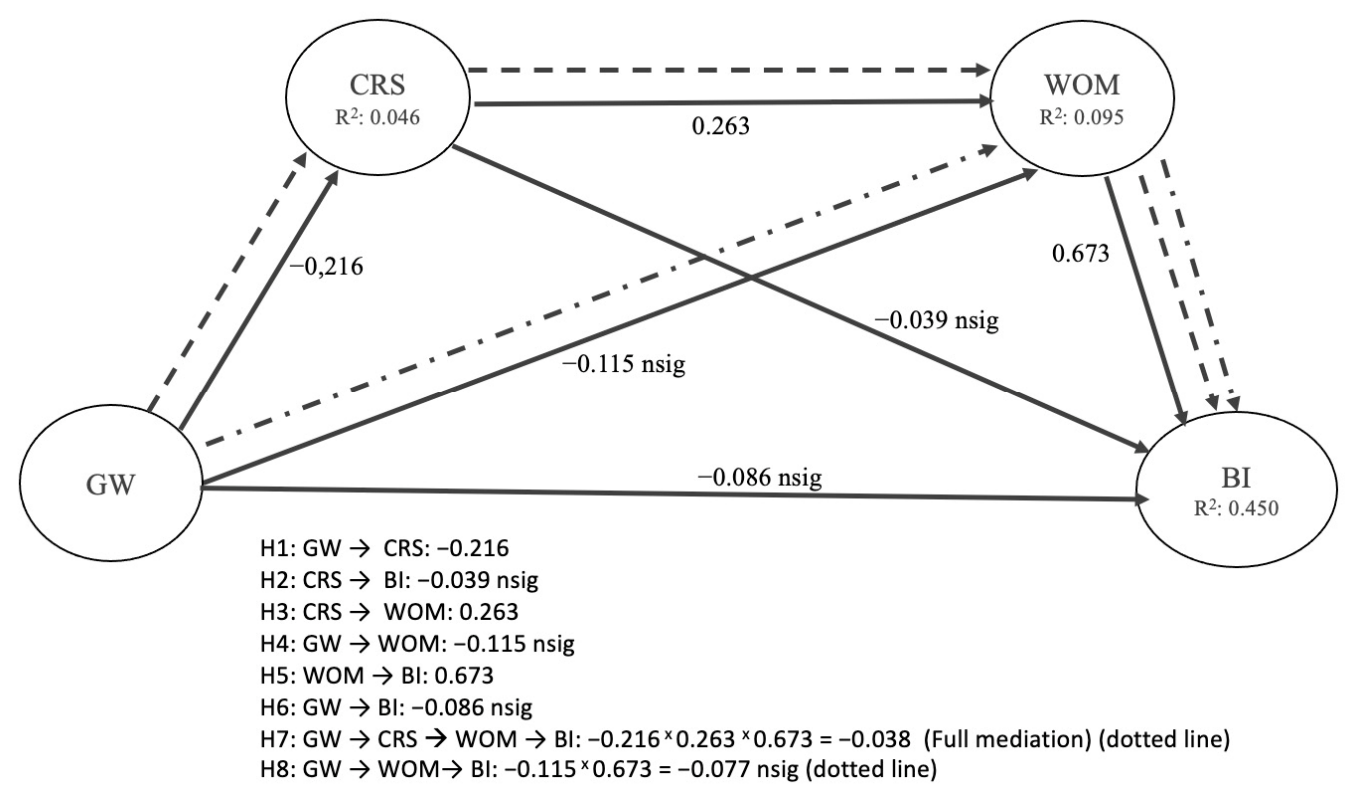

Figure 2. Research proposed model.

Table 4 shows the analysis of the proposed hypotheses in our research model.

In our research model, the analysis of direct relationships (Hypotheses 1 to 6) and indirect relationships (mediating effects of Hypotheses 7 and 8) were proposed. The indirect relationships are shown in Figure 2 with dotted and dashed lines. 


\section{Discussion}

After performing the corresponding analysis with the program SmartPLS we have to emphasize that four of the eight proposed hypotheses are fulfilled. Hypotheses H1, H3, H5 and $\mathrm{H} 7$ are fulfilled, this last one being the hypothesis formulated about total mediation of GW over BI through CSR and WOM.

From the results obtained, we can indicate in the first place, in relation to direct effects, $\mathrm{H} 1, \mathrm{H} 3$ and $\mathrm{H} 5$ are significant and therefore $\mathrm{H} 1, \mathrm{H} 3$ and $\mathrm{H} 5$ are supported. However, hypotheses $\mathrm{H} 2, \mathrm{H} 4$ and $\mathrm{H} 6$ turned out not to be significant and therefore have not been supported. Secondly, and in relation to mediating effects, H7 is significant, while H8 is not significant, and therefore $\mathrm{H} 7$ is supported and $\mathrm{H} 8$ is not.

In relation to H7, and according to Hair et al. (2017) and Nitzl et al. (2016), the type of mediation is full mediation because the direct effect between GW and BI (H6) is not significant, and the indirect effect, through the mediation of CSR and WOM, is significant.

It is noteworthy that the $\mathrm{H} 2$ hypothesis is not fulfilled since a good CSR policy improves the corporate image and reputation against what authors like Bigné-Alcañiz and Currás-Pérez say [39] but it does not affect BI. Hypotheses $\mathrm{H} 4$ and $\mathrm{H} 6$ are not fulfilled either, so a priori the GW only significantly affects CSR. This effect is in line with Mahoney et al. (2013). The proposed mediation of GW with BI through WOM is not significant either, but the total mediation (H7) is, this time accordingly to Bigné-Alcañiz and Currás-Pérez [39].

Among the significant relationships, it should be noted that all of them exceed the minimum recommended value of 0.2 . H1 has a path of -0.216 while $\mathrm{H} 3$ has 0.263 and H5 has the greatest contribution to the intention of use with 0.673 . We can also verify that the greatest contribution to the intention to use is made by word of mouth [83].

We must also highlight the strength of the relationship of hypothesis 5 since its $\mathrm{f} 2$ is 0.766, which is much higher than the recommended value [73]. This, together with the fact that the path between WOM and BI is 0.673 , makes this relationship the clearest of all those shown in the model.

\section{Conclusions}

We can emphasize that, once the model is proposed and the data collected in our field work is obtained, the results show us that the market knowledge of the unethical activities of the companies has a significant influence on different variables, which can influence the $\mathrm{BI}$ in a direct or indirect way.

GW has a significantly negative impact on the CSR. This influence can be due to the fact that the company may project a negative image to the outside, which influences consumer behavior. If the company transmits an image that is not very beneficial to it, the consumer will act accordingly, resulting in a decrease in the company's own income account.

CSR does not show an influence on BI. This shows us a somewhat surprising result not in line with the literature and we think that this may be due to the fact that the client of this type of business does not value much the responsibility of the company with the surrounding environment. Moreover, strengthening the previous argument, we add that other factors also have a greater influence on $\mathrm{BI}$, so it ends up nullifying or covering up the effect of CSR. While we have to emphasize that there is an indirect effect on BI mediated by CSR, so BI has indirect effects even in this type of business.

CSR has a significant and positive effect on WOM. A good image of a company is commented on and valued by consumers.

GW shows us that it does not have an influence on WOM. Here we discover another of the results of our work that is quite striking since it does not follow the line we expected. We think that this can be explained because either people do not understand well the philosophy of the GW concept to be transmitted or they consider that the argument is not important enough to transmit to other people or consumers. We could find that perhaps the client does not have enough information to judge and convey a negative or positive idea of the organization carrying out a false green strategy and that it only constitutes a claim to sell more by confusing individuals. We could also think that in this type of business 
the customer looks the other way in order to save money or obtain the service at a very competitive price.

WOM has an important and positive influence on BI. This seems logical, we understand that it is caused by the powerful effect generated by the opinions of other individuals/customers on other people's behaviour intention. The ideas that people transmit and that are received by other individuals are spread by individuals that are trusted by the receivers and who can influence their $\mathrm{BI}$ since these are people that the receiver trusts and believes in. Continuing with the above, customers trust the assessment and opinions of people who are in their closest circle, as they respect and value their opinion regarding their BI, far above the advertising claims of an ad or the statements of the companies' sellers or other reasons provided by other means of the firms.

GW does not have a significant relationship with BI, which may come as a surprise to us. To explain this, we believe that GW can be valued in a lesser degree in comparison with other variables that would camouflage its effect. That is, it is considered by the individual as more important than GW when generating his BI. Many times, the client is in a situation where he must choose between different reasons to generate his purchase intention that can influence his decision, and this leads him to discard options that are less ethical concerning the environment, because he feels that other incentives such as price, distribution or other variables are more influential in decision making and therefore the effect of GW is not considered.

However, we must point out that there is an indirect effect between GW and BI that is significantly in line with the proposed model and that it does remind customers that, although other reasons such as those set out in the previous paragraph may prevail, it is important not to have a GW policy.

\section{Limitations and Future Research}

Future lines of research would be to apply this research to other types of businesses, and also to other types of consumers with the aim of re-measuring the same relationships. We also consider that studying this now with the pandemic that is hitting us would be very appropriate to see if the results would change or be modified, which we see as very significant for carrying out a longitudinal study. It would also mean future research to see the relationship of GW with other variables such as sales or income accounts, or other variables, and to use samples from other countries to compare results at a cross-cultural level.

The relationship between CSR and BI could be measured in future studies using different samples of consumers, different types of companies and even using the opinion of company managers, and establishing comparisons with these results, which is a great future for research.

As limitations we would find what we have indicated previously, that it is a transversal study, that we only use a sample of consumers and that it is only for Spanish consumers, which limits the generalization of the results.

There is also limitation concerning the companies selected to perform the work. With these collaborative economy companies where low price prevails over almost any other consideration, it is difficult to generalize the results. It would be interesting to check companies from other sectors that are also susceptible to perform GW.

Author Contributions: Conceptualization, E.G.-C., J.P.C.-S., I.C.-C. and J.O.-G.; methodology, E.G.-C., J.P.C.-S., I.C.-C. and J.O.-G.; software, E.G.-C., J.P.C.-S., I.C.-C. and J.O.-G.; validation, E.G.-C., J.P.C.S., I.C.-C. and J.O.-G.; formal analysis, E.G.-C., J.P.C.-S., I.C.-C. and J.O.-G.; investigation, E.G.-C., J.P.C.-S., I.C.-C. and J.O.-G.; resources, E.G.-C., J.P.C.-S., I.C.-C. and J.O.-G.; data curation, E.G.-C., J.P.C.-S., I.C.-C. and J.O.-G.; writing-original draft preparation, E.G.-C., J.P.C.-S., I.C.-C. and J.O.-G.; writing-review and editing, E.G.-C., J.P.C.-S., I.C.-C. and J.O.-G.; supervision, E.G.-C., J.P.C.-S., I.C.-C. and J.O.-G.; project administration, E.G.-C., J.P.C.-S., I.C.-C. and J.O.-G.; funding acquisition, E.G.-C., J.P.C.-S., I.C.-C. and J.O.-G.; All authors have read and agreed to the published version of the manuscript.

Funding: This research received no external funding. 
Conflicts of Interest: The authors declare no conflict of interest.

\section{References}

1. Ottman, J.; Books, N.B. Green Marketing: Opportunity for Innovation. J. Sustain. Prod. Des. 1998, 60, $136-667$.

2. Polonsky, M.J. An Introduction to Green Marketing. Electron. Green J. 1994, 1, 1. [CrossRef]

3. Kilbourne, W.E. Green Marketing: A Theoretical Perspective. J. Mark. Manag. 1998, 14, 641-655. [CrossRef]

4. Chamorro, A.; Rubio, S.; Miranda, F.J. Characteristics of Research on Green Marketing. Bus. Strateg. Environ. 2009, 18, 223-239. [CrossRef]

5. $\quad$ Peattie, K.; Charter, M. Green Marketing. In The Marketing Book; Butterworth-Heinemann: Oxford, UK, 2003 ; pp. $726-755$.

6. Ginsberg, J.M.; Bloom, P.N. Choosing the Right Green Marketing Strategy. MIT Sloan Manag. Rev. 2004, 46, 79-84.

7. Kaman, L. Opportunities for Green Marketing: Young Consumers. Mark. Intell. Plan. 2008, 26, 573.

8. McDaniel, S.W.; Rylander, D.H. Strategic Green Marketing. J. Consum. Mark. 1993, 10, 4. [CrossRef]

9. Peattie, K. Towards Sustainability: The Third Age of Green Marketing. Mark. Rev. 2001, 2, 129-146. [CrossRef]

10. Prakash, A. Green Marketing, Public Policy and Managerial Strategies. Bus. Strateg. Environ. 2002, 11, 285-297. [CrossRef]

11. Grant, J. Green Marketing. Strateg. Dir. 2008, 24, 25. [CrossRef]

12. Nicola, M.; Michael, J.P. Using Strategic Alliances to Develop Credible Green Marketing. J. Consum. Mark. 1995, 12, 4-18.

13. Papadas, K.-K.; Avlonitis, G.J.; Carrigan, M.; Piha, L. The Interplay of Strategic and Internal Green Marketing Orientation on Competitive Advantage. J. Bus. Res. 2019, 104, 632-643. [CrossRef]

14. Widyastuti, S.; Santoso, B. Green Marketing: A Study of the Factors Influencing the Repurchase Decision for Javanony Herbal Products. Asean Mark. J. 2018, 125-135. [CrossRef]

15. Wang, P.; Kuah, A.T.H. Green Marketing Cradle-to-cradle: Remanufactured Products in Asian Markets. Thunderbird Int. Bus. Rev. 2018, 60, 783-795. [CrossRef]

16. Baktash, L.; Talib, M.A. Green Marketing Strategies: Exploring Intrinsic and Extrinsic Factors towards Green Customers' Loyalty. Calitatea 2019, 20, 127-134.

17. Marikyan, D.; Papagiannidis, S.; Alamanos, E. A Systematic Review of the Smart Home Literature: A User Perspective. Technol. Forecast. Soc. Chang. 2019, 138, 139-154. [CrossRef]

18. Pomering, A.A.; Johnson, L.W. Advertising Corporate Social Responsibility Initiatives to Communicate Corporate Image: Inhibiting Scepticism to Enhance Persuasion. Corp. Commun. Int. J. 2009, 14, 420. [CrossRef]

19. Polonsky, M.J.; Grau, S.L.; Garma, R. The New Greenwash? Potential Marketing Problems with Carbon Offsets. Int. J. Bus. Stud. 2010, 18, 49-54.

20. Watson, B. The Troubling Evolution of Corporate Greenwashing. Chain React. 2017, 129, 38-40.

21. Tinne, W.S. Green Washing: An Alarming Issue. ASA Univ. Rev. 2013, 7, 81-88.

22. Orange, E.; Cohen, A.M. From Eco-Friendly to Eco-Intelligent. Futurist 2010, 44, 28.

23. Cherry, M.A. The Law and Economics of Corporate Social Responsibility and Greenwashing. UC Davis Bus. LJ $2013,14,281$.

24. Cherry, M.A.; Sneirson, J.F. Chevron, Greenwashing, and the Myth of 'Green Oil Companies'. J. Energy Clim. Environ. 2012, 3, 133-154.

25. Parguel, B.; Benoît-Moreau, F.; Larceneux, F. How Sustainability Ratings Might Deter "Greenwashing": A Closer Look at Ethical Corporate Communication. J. Bus. Ethics 2011, 102, 15-28. [CrossRef]

26. Delmas, M.A.; Burbano, V.C. The Drivers of Greenwashing. Calif. Manag. Rev. 2011, 54, 64-87. [CrossRef]

27. Dellarmelin, M.L.; Moraes, J.P.; Hoeckesfeld, L.; Severo, E.A.; Hahn, I.S. The Influence of Green Branding on Purchase Intention, Willingness to Pay and Consumers' Emotional Response: An Experimental Study. Lat. Am. J. Manag. Sustain. Dev. 2018, 4, 69-82. [CrossRef]

28. Illia, L.; Rodríguez-Cánovas, B.; de la Brena, A.G.D.V. ¿Qué Piensan Los Directores Europeos Sobre Los Riesgos y Oportunidades de La Comunicación de La Responsabilidad Social Corporativa? Adres. ESIC Int. J. Commun. Res. Int. Investig. Comun. 2012, 6, 66-90.

29. Vogel, D. The Market. for Virtue: The Potential and Limits of Corporate Social Responsibility; Brookings Institution Press: Washington, DC, USA, 2006.

30. Kraus, S.; Richter, C.; Papagiannidis, S.; Durst, S. Innovating and Exploiting Entrepreneurial Opportunities in Smart Cities: Evidence from Germany. Creat. Innov. Manag. 2015, 24, 601-616. [CrossRef]

31. Lewis, S. Reputation and Corporate Responsibility. J. Commun. Manag. 2003, 7, 356-366. [CrossRef]

32. Habisch, A.; Wegner, M. Overcoming the Heritage of Corporatism. In Corporate Social Responsibility across Europe; Springer: Berlin/Heidelberg, Gemany, 2005; pp. 111-123.

33. Ramasamy, B.; Yeung, M.C.H.; Chen, J. Selling to the Urban Chinese in East Asia: Do CSR and Value Orientation Matter? J. Bus. Res. 2013, 66, 2485-2491. [CrossRef]

34. Gallicano, T.D. A Critical Analysis of Greenwashing Claims. Public Relat. J. 2011, 5, 1-21.

35. Holme, R.; Watts, P. Making Good Business Sense. Available online: https://pdfslide.net/documents/wbcsd-making-goodbusiness-sense.html (accessed on 13 June 2021).

36. Irshad, A.; Rahim, A.; Khan, M.F.; Khan, M.M. The Impact of Corporate Social Responsibility on Customer Satisfaction and Customer Loyalty, Moderating Effect of Corporate Image (Evidence from Pakistan). City Univ. Res. J. 2017, 1, 63-73. 
37. Chomvilailuk, R.; Butcher, K. Effects of Quality and Corporate Social Responsibility on Loyalty. Serv. Ind. J. 2014, 34, 938-954. [CrossRef]

38. Perri, C.; Giglio, C.; Corvello, V. Smart Users for Smart Technologies: Investigating the Intention to Adopt Smart Energy Consumption Behaviors. Technol. Forecast. Soc. Chang. 2020, 155, 119991. [CrossRef]

39. Bigne-Alcañiz, E.; Currás-Pérez, R. ¿Influye La Imagen de Responsabilidad Social En La Intención de Compra? El Papel de La Identificación Del Consumidor Con La Empresa. Universia Bus. Rev. 2008, 19, 10-23.

40. Pinillos, A.A.; Fernández, J.L. De La RSC a La Sostenibilidad Corporativa: Una Evolución Necesaria Para La Creación de Valor. Harvard-Deusto Bus. Rev. 2011, 207, 5-21.

41. Brown, J.J.; Reingen, P.H. Social Ties and Word-of-Mouth Referral Behavior. J. Consum. Res. 1987, 14, 350-362. [CrossRef]

42. Pepitone, A.; Katz, E.; Lazarsfeld, P.F. Personal Influence: The Part Played by People in the Flow of Mass Communications. Am. J. Psychol. 1957, 70, 157. [CrossRef]

43. Chen, Y.-S.; Chang, C.-H. Enhance Green Purchase Intentions: The Roles of Green Perceived Value, Green Perceived Risk, and Green Trust. Manag. Decis. 2012, 50, 502-520. [CrossRef]

44. Lyon, T.P.; Maxwell, J.W. Greenwash: Corporate Environmental Disclosure under Threat of Audit. J. Econ. Manag. Strateg. 2011, 20,3-41. [CrossRef]

45. Chen, Y.-S.; Lin, C.-L.; Chang, C.-H. The Influence of Greenwash on Green Word-of-Mouth (Green WOM): The Mediation Effects of Green Perceived Quality and Green Satisfaction. Qual. Quant. 2014, 48, 2411-2425. [CrossRef]

46. Wallace, E.; Buil, I.; de Chernatony, L. Consumer Engagement with Self-Expressive Brands: Brand Love and WOM Outcomes. J. Prod. Brand Manag. 2014, 23, 33. [CrossRef]

47. Yang, J.; Kim, W.; Amblee, N.; Jeong, J. The Heterogeneous Effect of WOM on Product Sales: Why the Effect of WOM Valence Is Mixed? Eur. J. Mark. 2012, 46, 1523. [CrossRef]

48. Zhang, L.; Li, D.; Cao, C.; Huang, S. The Influence of Greenwashing Perception on Green Purchasing Intentions: The Mediating Role of Green Word-of-Mouth and Moderating Role of Green Concern. J. Clean. Prod. 2018, 187, 740-750. [CrossRef]

49. Zeithaml, V.A.; Berry, L.L.; Parasuraman, A. The Behavioral Consequences of Service Quality. J. Mark. 1996, 60, 31-46. [CrossRef]

50. Martin, D.; O'Neill, M.; Hubbard, S.; Palmer, A. The Role of Emotion in Explaining Consumer Satisfaction and Future Behavioural Intention. J. Serv. Mark. 2008, 22, 224. [CrossRef]

51. Di Pietro, L.; Di Virgilio, F.; Pantano, E. Social Network for the Choice of Tourist Destination: Attitude and Behavioural Intention. J. Hosp. Tour. Technol. 2012, 3, 60. [CrossRef]

52. Vijayadurai, J. Service Quality, Customer Satisfaction and Behavioural Intention in Hotel Industry. J. Mark. Commun. 2008, 3 , $14-26$.

53. Cronin, J.J., Jr.; Brady, M.K.; Hult, G.T.M. Assessing the Effects of Quality, Value, and Customer Satisfaction on Consumer Behavioral Intentions in Service Environments. J. Retail. 2000, 76, 193-218. [CrossRef]

54. Barsky, J.; Nash, L. Evoking Emotion: Affective Keys to Hotel Loyalty. Cornell Hotel Restaur. Adm. Q. 2002, 43, 39-46. [CrossRef]

55. Lee, J.-S.; Hsu, L.-T.; Han, H.; Kim, Y. Understanding How Consumers View Green Hotels: How a Hotel's Green Image Can Influence Behavioural Intentions. J. Sustain. Tour. 2010, 18, 901-914. [CrossRef]

56. Balta-Ozkan, N.; Amerighi, O.; Boteler, B. A Comparison of Consumer Perceptions towards Smart Homes in the UK, Germany and Italy: Reflections for Policy and Future Research. Technol. Anal. Strateg. Manag. 2014, 26, 1176-1195. [CrossRef]

57. Essoussi, L.H.; Zahaf, M. Exploring the Decision-Making Process of Canadian Organic Food Consumers. Int. J. 2009, 12, 443-459.

58. Chen, H.; Bernard, S.; Rahman, I. Greenwashing in Hotels: A Structural Model of Trust and Behavioral Intentions. J. Clean. Prod. 2019, 206, 326-335. [CrossRef]

59. Song, J.; Koo, C.; Kim, Y. Investigating Antecedents of Behavioral Intentions in Mobile Commerce. J. Internet Commer. 2008, 6, 13-34. [CrossRef]

60. Lee, S.; Park, E.; Kwon, S.J.; Del Pobil, A.P. Antecedents of Behavioral Intention to Use Mobile Telecommunication Services: Effects of Corporate Social Responsibility and Technology Acceptance. Sustainability 2015, 7, 11345-11359. [CrossRef]

61. Laufer, W.S. Social Accountability and Corporate Greenwashing. J. Bus. Ethics 2003, 43, 253-261. [CrossRef]

62. Goyette, I.; Ricard, L.; Bergeron, J.; Marticotte, F. E-WOM Scale: Word-of-mouth Measurement Scale for E-services Context. Can. J. Adm. Sci. Can. Sci. Adm. 2010, 27, 5-23. [CrossRef]

63. Xu, Y.; Summers, T.A.; Belleau, B.D. Who Buys American Alligator?: Predicting Purchase Intention of a Controversial Product. J. Bus. Res. 2004, 57, 1189-1198. [CrossRef]

64. Rigdon, E.E. Choosing PLS Path Modeling as Analytical Method in European Management Research: A Realist Perspective. Eur. Manag. J. 2016, 34, 598-605. [CrossRef]

65. Alalwan, A.A.; Dwivedi, Y.K.; Rana, N.P. Factors Influencing Adoption of Mobile Banking by Jordanian Bank Customers: Extending UTAUT2 with Trust. Int. J. Inf. Manag. 2017, 37, 99-110. [CrossRef]

66. Rigdon, E.E.; Sarstedt, M.; Ringle, C.M. On Comparing Results from CB-SEM and PLS-SEM: Five Perspectives and Five Recommendations. Mark. Zfp 2017, 39, 4-16. [CrossRef]

67. Dijkstra, T.K.; Henseler, J. Linear Indices in Nonlinear Structural Equation Models: Best Fitting Proper Indices and Other Composites. Qual. Quant. 2011, 45, 1505. [CrossRef]

68. Dijkstra, T.K.; Henseler, J. Consistent Partial Least Squares Path Modeling. MIS Q. 2015, 39, 297-316. [CrossRef] 
69. Henseler, J. Partial Least Squares Path Modeling. In Advanced Methods for Modeling Markets; Springer: Berlin/Heidelberg, Germany, 2017; pp. 361-381.

70. Hair, J.F., Jr.; Hult, G.T.M.; Ringle, C.; Sarstedt, M. A Primer on Partial Least Squares Structural Equation Modeling (PLS-SEM); Sage Publications: Thousand Oaks, CA, USA, 2016.

71. Henseler, J. Partial Least Squares Path Modeling: Quo Vadis? Qual. Quant. 2018, 52, 1-8. [CrossRef]

72. Hair, J.F.; Risher, J.J.; Sarstedt, M.; Ringle, C.M. When to Use and How to Report the Results of PLS-SEM. Eur. Bus. Rev. 2019, 31, 2-24. [CrossRef]

73. Chin, W.W. The Partial Least Squares Approach to Structural Equation Modeling. Mod. Methods Bus. Res. 1998, $295,295-336$.

74. Carrión, G.C.; Nitzl, C.; Roldán, J.L. Mediation Analyses in Partial Least Squares Structural Equation Modeling: Guidelines and Empirical Examples. In Partial Least Squares Path Modeling; Springer: Berlin/Heidelberg, Germany, 2017; pp. $173-195$.

75. Henseler, J.; Ringle, C.M.; Sarstedt, M. A New Criterion for Assessing Discriminant Validity in Variance-Based Structural Equation Modeling. J. Acad. Mark. Sci. 2015, 43, 115-135. [CrossRef]

76. Nunnally, J.C. Psychometric Theory; McGraw-Hill Book Company Inc.: New York, NY, USA, 1978.

77. Fornell, C.; Larcker, D.F. Structural Equation Models with Unobservable Variables and Measurement Error: Algebra and Statistics; Sage Publications Sage CA: Los Angeles, CA, USA, 1981.

78. Hair, J.F., Jr.; Sarstedt, M.; Hopkins, L.; Kuppelwieser, V.G. Partial Least Squares Structural Equation Modeling (PLS-SEM). Eur. Bus. Rev. 2014, 26, 106-121. [CrossRef]

79. Henseler, J.; Ringle, C.M.; Sarstedt, M. Testing Measurement Invariance of Composites Using Partial Least Squares. Int. Mark. Rev. 2016, 33, 405-431. [CrossRef]

80. Nunnally, J.C. Psychometric Theory, 3rd ed.; Tata McGraw-Hill Education: New Delhi, India, 1994.

81. Werts, C.E.; Linn, R.L.; Jöreskog, K.G. Intraclass Reliability Estimates: Testing Structural Assumptions. Educ. Psychol. Meas. 1974, 34, 25-33. [CrossRef]

82. Efron, B.; Tibshirani, R. Bootstrap Methods for Standard Errors, Confidence Intervals, and Other Measures of Statistical Accuracy. Stat. Sci. 1986, 1, 54-75. [CrossRef]

83. Chang, J.-I.; Lee, C.-Y. The Effect of Service Innovation on Customer Behavioral Intention in the Taiwanese Insurance Sector: The Role of Word of Mouth and Corporate Social Responsibility. J. Asia Bus. Stud. 2020, 14, 341-360. [CrossRef] 